\title{
Nie przeoczyć teraz - filozofia codzienności Janusza Korczaka
}

\author{
Summary \\ Not to overlook the present - Janusz Korczak's philosophy of everyday life \\ In this paper, I focus on one of the children's rights, which Janusz Korczak raised in his writings, \\ namely the child's right to the present day, which I understand as a postulate to appreciate the dignity \\ of a child in its everyday life. My aim in this paper is, therefore, not only to reconstruct and uncover \\ the complexities of this postulate, but also to theoretically embed this concept in pedagogical nar- \\ ratives about the child, and more specifically in anthropology of education and upbringing. In order \\ to achieve this aim, 1. I will describe two paths in thinking about the relationship between human \\ beings and their culture, taking into account especially its temporal dimension. Then I will proceed \\ to 2. the concept of children's rights in Korczak's understanding of the child subjectivity; in order to \\ indicate 3. the radical and ethical character of message his thinking.
}

Keywords: Janusz Korczak, responsibility, child, adult

Słowa kluczowe: Janusz Korczak, odpowiedzialność, dziecko, dorosły

$\mathrm{W}$ artykule tym koncentruję się na jednym z praw dziecka, które podnosił w swoich pismach Janusz Korczak, mianowicie - prawie dziecka do dnia dzisiejszego, które rozumiem jako postulat docenienia godności dziecka w jego codziennożyciowej egzystencji. Celem niniejszego artykułu jest nie tylko rekonstrukcja i odsłonięcie zawiłości towarzyszących temu postulatowi, lecz także teoretyczne osadzenie tego konceptu w narracjach pedagogicznych na temat dziecka, a konkretnie - w pewnej antropologii edukacji i wychowania. Aby cel ten zrealizować, opiszę w pierwszej kolejności ścieżki w myśleniu na temat relacji człowieka i jego kultury, angażując ich przede wszystkim temporalny wymiar, następnie przejdę do koncepcji praw dziecka w rozumieniu Korczaka względem podmiotowości dziecięcej po to, aby wskazać radykalność i etyczne przesłanie jego myślenia.

Zestawiam ze sobą dwa podstawowe sensy edukacji wytworzone w zorientowanym antropologicznie dyskursie pedagogicznym, chciałbym je uczynić pewnymi punktami granicznymi dla różnorodnych konceptów pedagogicznych, do których się odwołujemy, tworząc wyjaśnienia sytuacji edukacyjnych, a szerzej - społecznych. Owo „zorientowanie antropologiczne" oznacza, że podstawową kategorią rozumienia oraz stosowanego tu podziału jest kultura. Nie wikłając się w tym momencie w subtelności dotyczące wie- 
loznaczności tego terminu, przyjmuję, posiłkując się myślą Antoniny Kłoskowskiej, że kultura oznacza względnie zintegrowaną całość ludzkich wzorów rozumienia świata, kreowania na ich podstawie zachowań i relatywnego ich reprodukowania w toku interakcji społecznych (Kłoskowska 1980: 40). Tak określona kultura obejmuje sferę zarówno idei, stosunków społecznych, jak i „,naturalnego”, materialnego oprzyrządowania obu poprzednich sfer, przede wszystkim zaś jest ukierunkowana - na co zwraca uwagę Bogdan Nawroczyński - na wytwarzanie wartości przekładających się na istniejące w danej społeczności lub jej części systemy normatywne (Nawroczyński 1947). Biorąc to pod uwagę, uznaję, że kultura jest właściwym człowiekowi środowiskiem jego życia, a oznacza to, że: 1. proponowany dyskursywnie sens edukacji jest związany z wizją kultury i w konsekwencji: 2 . wizja kultury oddziałuje (silnie lub słabo) na określanie ideałów, celów, podmiotów i okoliczności edukacji.

Wychodząc zatem od określenia środowiska życia człowieka jako kultury, czyli złożonej całości wzorów potrzebnych do funkcjonowania między ludźmi, można wyróżnić można dwa modele, „typy idealne” (Weber 2002) edukacji, które traktuję jako narzędzia heurystyczne (a nie oceniające). Jeden z nich określam jako przygotowanie do odbioru kultury, drugi zaś jako uczestnictwo w kulturze.

Podstawową ideą, którą kieruje się typ pierwszy, jest szeroko pojęta niegotowość do jej odbioru. Echa takiego podejścia można odnaleźć już w pierwszych systemach filozoficznych: idealizmie Platona i realizmie Arystotelesa, które zawierały przesłanie edukacyjne i zarazem wyraźnie oddziaływały na późniejsze koncepcje wychowania i edukacji. Niegotowość ta dotyczy wszystkich możliwych wyposażeń człowieka. Prym wiedzie tutaj myślenie o edukacji jako „prowadzeniu” przez dorosłych i „wyprowadzaniu” ze „stanu natury” do „stanu kultury”, głównie przez świat symboli. Platońska koncepcja anamnezy wyraźnie wskazuje na dzieciństwo jako na okres „zapomnienia”, z którego wyjść można dopiero za pomocą odpowiednich procedur opartych na modelowaniu, gdzie modelem jest dorosły/nauczyciel. Tym samym niegotowość to niedojrzałość struktur poznawczych i behawioralnych do zrozumienia przez dziecko idei Dobra, którym posługują się (a w każdym razie powinny posługiwać się) wyższe od niego (w sensie zarówno metaforycznym, jak i dosłownym) struktury społeczne (Strain 1975). Podobnie rozumował Arystoteles i jego następcy: rozwijać w dziecku należy to, co jest jego najcenniejszą zdolnością, czyli umiejętność racjonalnego myślenia. Ta zaś umiejętność może być kształtowana tylko dzięki dostarczaniu mu uprzednio uporządkowanej wiedzy o świecie.

Kultura jest tu rozumiana jako negacja natury po to, by podkreślić kulturową „,naturę ludzką". Proces nabywania kultury: enkulturacja lub socjalizacja, opisywany jest jako siła wyrywająca człowieka ze „stanu natury” ku pełnemu człowieczeństwu, polegającemu na wytworzeniu swego rodzaju ,świadomości zbiorowej”, funkcjonującej dzięki wspólnemu wysiłkowi dorosłych jej członków. I choć zazwyczaj w podręcznikach do historii myśli pedagogicznej przeciwstawia się sobie takich klasyków „stanu natury”, jak John Locke i Jean-Jacques Rousseau, to - pomimo wielu rzeczywistych różnic - wypada się zgodzić z Neilem Postmanem, że: „Ani Locke, ani Rousseau nigdy nie wątpili, że dzieciństwo 
wymaga zorientowanego na przyszłość przewodnictwa dorosłych" (Postman 2001: 133). Nikt zatem człowiekiem się nie rodzi, a dopiero się nim staje w wyniku społecznych i kulturowych oddziaływań, zapewniających przyjęcie tych powszechnie respektowanych w danej społeczności przekonań. Przygotowanie do odbioru kultury wymaga zatem całego zespołu środków, dzięki którym dziecko może i powinno „dochodzić” do pełnego (albo przynajmniej częściowego) rozwoju, czyli wykorzystania dziedzictwa wypracowanego przez dorosłych. Tym samym w koncepcji kultury jako działań przygotowawczych silny nacisk kładzie się na przekaz kultury, przekaz głównie obiektywnych/uniwersalnych treści oraz jej transmisję międzygeneracyjną sprzężoną z różnymi formami kontroli społecznej (Tillmann 2013: 113-117), zakładając jednocześnie sporą dozę „zdrowego” konformizmu plastycznych obiektów edukacyjnych (Kohlberg, Mayer 2000: 24-25).

W modelu edukacji jako przygotowania do odbioru kultury uwidacznia się również inny silny podział. Język jest tu pełen dystynkcji podkreślających nie tylko niegotowość, ale też odgrywane role: dziecka vs rodzica, ucznia vs nauczyciela, młodzieży vs dorosłego, gdzie generalnie ten drugi element ma kulturową przewagę nad tym pierwszym: jest wzorcem, ideałem, modelem, znaczącym Innym, kompetentnym realizatorem kultury itd. Dzieje się to zgodnie z ideą hierarchicznej struktury bytów, przyjętej już w starożytności i obowiązującej aż po XIX wiek, którą określa się jako „wielki łańcuch bytu” (Lovejoy 1999). Według niej wszelkie możliwe formy bytów tworzą ciągłą hierarchię - od form niższych ku wyższym. Istnienie i znaczenie dziecka w kontekście tej idei może być zatem interpretowane wyłącznie lub niemal wyłącznie przez brak tego, co posiadają dorośli jako kompetentni członkowie kultury, dorosłość zaś - odwrotnie - jako wyzbycie się tego, co dziecięce. Ta silna separacja tego, co dziecięce, i tego, co dorosłe, prowadzi do uznania, również przez pedagogikę oświeceniową - a więc generalnie wrażliwą na dziecko, że „dziecko jest nieporównywalną z dorosłymi kanonami istotą”, choć jednocześnie powinno być „wedle tych kanonów oceniane”, ponieważ to one wyznaczają fundament przyszłego, lepszego społeczeństwa (Buliński 2002: 163). Dziecko jest więc istotą jeszcze nie - niegotową, niezdolną, niedorosłą.

Z kolei koncepcja edukacji rozumianej jako uczestnictwo w kulturze wywodzi się od inaczej zorientowanej antropologii, kładącej nacisk na kulturę nie tyle jako ramę czy system (choć nie neguje się ich istnienia), ile jako praktykę realizacji różnorodnych ludzkich potrzeb. Myślą przewodnią takiego ujęcia jest szeroko pojęte kontekstualne osadzenie świadomości użytkowników kultury. Wyraża ono, z jednej strony, głęboką nieufność wobec dobroczynnych skutków wzmożonej pracy nad integracją kulturową (Archer 2019: 97-126), z drugiej zaś względnie głęboką ufność w możliwość podjęcia racjonalnego dialogu reorganizującego istniejące relacje społeczne (Kant 1995: 53-60). Początki takiej wizji kultury można odnaleźć już u starożytnych sofistów i sceptyków, którzy wyrażali sprzeciw wobec dogmatycznych i uniwersalistycznych roszczeń Platona i Arystotelesa, kładąc jednocześnie nacisk na poszukiwanie takich form ekspresji, które pozwalają jednostkom aktywnie uczestniczyć w zmieniającym się świecie. Anhtropos metron Protagorasa zakorzenia w europejskim sposobie myślenia o człowieku wagę indywidualnego 
doświadczenia świata i siebie samego, a także wielość języków - uzależnionych od przeżywanych okoliczności - służących do opisu tych doświadczeń.

Jest jednak oczywiste dla tego typu myślenia o edukacji, że indywidualny kontekst świadomości nie jest i być nie może jedyną miarą rozumienia swoich działań, są one bowiem wpisane w już istniejącą kulturową sieć znaczeń, również językowych. Powoływane przez człowieka instytucje kulturowe mają jednak nie tyle służyć kontroli jego zachowania wobec społecznego otoczenia, ile raczej są pojmowane jako narzędzia adaptacji społecznej, a sama adaptacja zaś ma być postrzegana nie tyle jako przystosowanie się do wymogów zewnętrznych okoliczności, ile raczej jako refleksyjne rozpoznanie fizycznych (przyrodniczych) i społecznych okoliczności swojego działania, którego celem jest przekształcenie lub zachowanie warunków potencjału rozwojowego (Bruner 2006). Dlatego też niezasadne jest utrzymywanie jako istotnego podziału na deterministyczną „,naturę” i podporządkowaną jej „kulturę”, jako że nie dysponujemy dostępem poznawczym do jakiejś „,czystej” (tj. ludzko niezapośredniczonej) natury; przeciwnie, wiele przemawia za tym, aby takie określenia, jak „natura ludzka” czy „natura dziecka”, traktować jako metafory w toczących się codziennie grach językowych. Ponadto podejście takie podkreśla „,indywidualny udział w zjawiskach kultury - przyswajanie jej treści, używanie jej dóbr, podleganie obowiązującym w niej normom i wzorom, ale także tworzenie nowych jej wartości oraz odtwarzanie i przetwarzanie istniejących" (Tyszka 1971: 54). Można z tego wyprowadzić wniosek o niezbywalnym pluralizmie aktorów społecznych, których odmienne położenia i doświadczenia prowadzą do wytwarzania przez nich skomplikowanych i przenikających się wzajemnie układów społecznych. Te odmienne położenia i doświadczenia w omawianym modelu są odczytywane jako okoliczności tychiczne (James 1998), jako sposobności sprzyjające redefinicji zastanych (czy narzuconych) określeń społecznych. Dlatego też zadaniem edukacji jest ,pobudzanie podmiotowej kreatywności, zdolności człowieka do sterowania własnym życiem, samokształcenia, samoedukacji, potrzeby stymulowania sił duchowych i dyspozycji dotąd pozostających w uśpieniu" (Wojnar 2000: 189).

Perspektywa ta wyznacza również sposób określania relacji między dzieckiem a dorosłym. O ile pierwszy omówiony typ edukacji określa się jako androcentryczny, skłonny widzieć dorosłego jako pełnoprawnego reprezentanta świata (Śliwerski 2007: 67), o tyle drugi podkreśla nie tylko zdolność dziecka do uczenia się (tj. nabywania kultury dorosłych), ale także - a może przede wszystkim - jego wrodzone kompetencje do samostanowienia. Koncepcje człowieka wywodzące się z pragmatyzmu, egzystencjalizmu, psychologii humanistycznej oraz wielu teorii pedagogicznych od Pestalozziego poczynając, nakazują odrzucić taką wizję dziecka (wywodzącą się mi.in. z idealizmu, realizmu, funkcjonalizmu i behawioryzmu), w której to dorośli stanowią ,naturalną” bazę do rozwoju predyspozycji dziecka, na rzecz takiej, w której przyjmuje się, że dziecko jest już-zdolne, gotowe, we właściwym miejscu, a to nam, dorosłym, co najwyżej brakuje możliwości zrozumienia jego możliwości i potrzeb (Szczepska-Pustkowska 2011). Taka „orientacja na dziecko" powinna skutkować nie tylko przyznaniem dzieciom tych samych praw, któ- 
re posiadają dorośli, ale przede wszystkim podaniem w wątpliwość ostrego rozróżnienia powszechnie nadużywanych określeń: „dorosły” i „dziecko”. W tym też sensie perspektywa ta ukazuje, że kultura nie jest od człowieka oddalona, lecz jest jego codziennością i zmienną aktualnością, której zrozumienie i usytuowanie we własnym kontekście jest jego zadaniem jako osoby orientującej się w swoim życiu.

Myśl i działalność pedagogiczna Janusza Korczaka wpisuje się w drugi z opisywanych tu typów rozumienia edukacji i wychowania. Jednoznacznie staje on po stronie tych, którzy wychowanie rozumieją jako współwytwarzanie świata z drugim człowiekiem. W licznych opracowaniach jego twórczości słusznie znajdują się nawiązania do idei Nowego Wychowania oraz progresywizmu, których przedstawiciele byli głównymi orędownikami edukacji jako uczestnictwa w kulturze (np. Olczak-Ronikier 2011; Smolińska-Theiss 2013), jednocześnie wyraźny nacisk kładzie się w nich na zapewnienie prawnych podstaw tego uczestnictwa. Wydaje się jednak, że Korczak jest radykalniejszy w swoim myśleniu na temat praw dziecka, dostrzega bowiem, że samo zaistnienie przepisów „chroniących” dzieci nie jest warunkiem skutecznego rozwoju dziecka, do tego potrzebne jest przeorientowanie myślenia nie tylko o dziecku, ale również o dorosłym oraz o łączących ich relacjach.

Już w zbiorze esejów zatytułowanym Jak kochać dziecko, wydanym w 1919 roku, nawołuje do głośnego dopominania się o prawa dziecka, a jego wypowiedź przybiera ton żądania:

Baczność! Albo porozumiemy się teraz, albo rozejdziemy się na zawsze. Każda myśl, która pragnie się wymknąć i ukryć, każde wałęsające się samopas uczucie winny być przywołane do porządku i ustawione w karnym szeregu przez wysiłek woli. Wzywam o Magna Charta Libertatis o prawa dziecka. Może jest ich więcej, ja odszukałem trzy zasadnicze:

1. Prawo dziecka do śmierci.

2. Prawo dziecka do dnia dzisiejszego.

3. Prawo dziecka, by było tym, czym jest (Korczak 1958b: 110-111).

Tak przedstawionym prawom dziecka zdecydowanie bliżej do refleksji moralnej człowieka wobec świata niż do skrupulatnych przepisów prawnych, których przekroczenie lub nieprzestrzeganie miałoby skutkować karnymi sankcjami. Nie oznacza to jednak, że pewne - jak dziś byśmy powiedzieli - prawa podstawowe dziecka nie powinny znajdować swoich prawnych uregulowań; zakaz przemocy fizycznej i psychicznej, prawo do prywatności, prawo do opieki zdrowotnej i inne - włączając w nie nawet prawo do śmierci - takie przepisy łatwo skonstruować, ponieważ względnie łatwo ich przestrzegać. A dzieje się tak z pewnością, ponieważ są one prawami dorosłych ustalonymi dla dorosłych, a teraz rozciągniętymi nad dziećmi jako rodzaj - słusznie zapewne istniejącego w wielu wypadkach - parasola ochronnego. I przynajmniej niektóre z tych praw były wpisane do przyjętej przez Ligę Narodów w 1924 roku Deklaracji genewskiej, do której odnosił się Korczak jako autor Prawa dziecka do szacunku. 
Korczak zdaje się jednak czynić dwa poważne zarzuty wobec tak rozumianej idei praw dziecka. Pierwszy zarzut wyraża następująco: „Prawodawcy genewscy pomieszali obowiązki i prawa; ton deklaracji jest perswazją, nie żądaniem: apel do dobrej woli, prośba o życzliwość" (Korczak 1958c: 411). Te niezwykle emocjonalnie nacechowane, brzmiące jak skarga stwierdzenia następują po równie silnym ataku na niesprawiedliwą sytuację dziecka: „Dziecko musi żebrać u rodziców lub gminy, podlegając przymusowi powszechnego nauczania” (Korczak 1958c: 411). Wypowiedzi te wyraźnie wskazują na kontekst myślenia o prawach dziecka, które zamienione na nieuwzględniające i nierozpoznające aktualnych potrzeb i motywacji dziecka przepisy mogą mieć skutek odwrotny od zamierzonego. Kiedy bowiem mówi się o prawie dziecka do edukacji, do nauki, ma się przede wszystkim na myśli to, że do tej pory szkoły lub miejsca, gdzie naukę można było pobierać, były zarezerwowane dla nielicznych dzieci. W tym żądaniu (jak chciałby Korczak) uwidacznia się sprzeciw wobec braku dostępu do społecznych instytucji kształcących i rozwijających psychiczne i intelektualne zdolności człowieka. Jednak zaspokojenie tego żądania doprowadziło do sprzeczności z podstawową intuicją tego prawa: prawo stało się przykrym obowiązkiem i przymusem. Przekształcenie prawa do edukacji w system oświaty z nadrzędną funkcją kontroli i posłuszeństwa wobec starszych i przełożonych skutkuje społecznym przywiązaniem do takiej formy edukacji i sprawia, że - jak zauważa Peter Hartkamp, przedstawiciel Europejskiego Stowarzyszenia Edukacji Demokratycznej - „System obowiązkowej edukacji indoktrynuje tak skutecznie, że większość ludzi uwierzyła, że jest to jedyny sposób, w jaki można uczyć dzieci. Ten rodzaj szkolnictwa zdaje się nową religią" (Hartkamp 2017: 24). Pierwsze zastrzeżenie dotyczy więc rozróżnienia prawa naturalnego i prawa stanowionego (pozytywnego).

Drugie zastrzeżenie, które czyni Korczak, a które w moim przekonaniu jest jeszcze ważniejsze niż pierwsze, o zamianę w tym zakresie jeszcze trudniej niż w pierwszym wypadku, dotyczy tych praw, których nie da się sformułować w postaci przepisów, a które są niezbędne do społecznego funkcjonowania jednostek, jakimi są dzieci. To prawa moralne wynikające z porządku istnienia wszystkich istot, którym przypisywana jest zdolność do istnienia. Korczak nad wyraz świadomie pisze, że: „nie ma dzieci, są ludzie”, nie dlatego że chce, aby dzieci upodobniły się do pewnej formy dorosłości w wyniku ich (dorosłych) działania, co i tak w pewnym momencie się stanie, ale dlatego, że chce, aby dzieci otrzymały od dorosłych świadomą autonomię bądź też bardziej precyzyjnie - autonomia dziecka polega na uznaniu przez dorosłych, że świat dziecięcy, z całą swoją zmiennością i ruchliwością, nie jest wcale mniej ważny i mniej doskonały niż świat dorosłych, któremu do doskonałości niezwykle daleko (i słusznie). Dlatego też prawa dziecka u Korczaka przybierają charakter postulatu etycznego i choć on sam nie odwołuje się wprost do imperatywu kategorycznego Kanta, to jest on implicite zawarty w poszukiwaniach autora Prawa dziecka do szacunku. Takiego zaś prawa moralnego nie sposób uczynić przedmiotem prawa pozytywnego bez uszczerbku dla prawa moralnego, w każdym bowiem spotkaniu z dzieckiem, w każdej sytuacji wychowawczej musimy jako dorośli określać, co to jest szacunek, którego dziecko potrzebuje dziś i teraz. Pozytywnoprawnie zaś trzeba wybierać 
to, co da się jurydycznie unaocznić i regulatywie dookreślić, tworząc częstokroć alternatywną wobec potrzeb i możliwości dziecka i dorosłego teraźniejszość. Drugie zatem zastrzeżenie dotyczy rozróżnienia „teraz” i teraźniejszości.

To, z czym mamy do czynienia $\mathrm{w}$ trakcie wychowania, to przede wszystkim relacja opisująca spotkanie ludzi uwikłanych - z mniejszym lub większym poziomem rozumienia - w systemy znaczeń. Spotkanie to korzysta ze wspólnych kulturowych zasobów, które jednak przejawiają się poprzez konkretne użycia konkretnych jednostek. Codzienność („teraz”) wychowania polega na bezpośrednim doświadczaniu przez jednostkę momentów wychowawczych, tzn. zarówno tego, czego się doświadczyło, jak i tego, czego pozwoliło się doświadczyć Innemu w biegu życia. Teraźniejszość zaś wychowania jest wrzuceniem w sieci kultury, których położenia i znaczenia nie są w jego trakcie ani rozumiane, ani poddane refleksji. Oto Korczakowski opis kultury teraźniejszości: „Drwiną, że dziecko nie wie, zabijasz w nim chęć dowiedzenia się. Kto przyzna się, że nie czytał Fausta, nie widział Rubensa, nie wie, kto był Pestalozzi? I czytamy, aby zbyć, patrzymy, aby zbyć, wiemy wszystko byle jak - cywilizację robią jednostki, politykę robią kliki, zaś ogół durny - za nos wodzony - umiera nawet, a wstydzi się przyznać, że nie wie za co, byle się nie śmiano z niego. Kto się śmieje z trzyletniego dziecka, że chce gwoździkami przybić szkiełka do oczów - jest zdrajcą, deprawatorem" (Korczak 1958a: 36-37). Pozytywny, etyczny wymiar tego spotkania polega nie na wtrącaniu podmiotów tej relacji w teraźniejszość, wobec której są - pozornie lub rzeczywiście - bezradni i często zagubieni, lecz na wzajemnym angażowaniu się w rozumienie siebie w bezpośrednim doświadczeniu wspólnego życia.

Korczak uważnie przygląda się nie tylko światu dziecka, ale również światu dorosłych. Radykalizm jego myślenia polega przede wszystkim na bezwzględnej uczciwości wobec tych dwóch światów, z którymi ma do czynienia. Pozornie bowiem nie przekreśla zwykłej codziennej troski, którą wyrażają dorośli względem dziecka, pytając o to, co z owego konkretnego dziecka „wyrośnie” - pytania takie ściśle związane są z odpowiedzialnością rozumianą jako odpowiedzialność za kogoś i są całkowicie zrozumiałe na gruncie powszechnie przyjętego paradygmatu myślenia o dziecku jako istocie jeszcze nie. Niwelowanie tych dziecięcych „braków” także podejmowane w imię tak rozumianej troski. Może to jednak - jego zdaniem - prowadzić do sytuacji, w której dziecko, nie spełniwszy pokładanych w nim nadziei i oczekiwań, stanie się wymówką (okazją negatywną) ukrywającą egoizm wychowawczy dorosłych. Korczak doskonale w tym kontekście odtwarza myślenie dorosłych, gdy pisze: „Porozumieliśmy się z sobą i pogodzili, wybaczyli i zwolnili z obowiązku poprawy. Źle nas wychowano. Za późno. Już wady i przywary zakorzenione. Nie pozwalamy dzieciom krytykować ani się sami kontrolujemy. Rozgrzeszeni zrzekliśmy się walki z sobą obarczając ciężarem jej dzieci" (Korczak 1958c: 416). Świat dorosłych jest tu postrzegany jako zanurzony w absolutnej teraźniejszości, z której wydrenowano przede wszystkim wolę zmiany swojego statusu i wolę zmiany podejścia do tych, których rzekomo się kocha, na dzieci ceduje się obietnicę świetlanej - a przez to niemożliwej do realizacji - przyszłości. 
To działanie i myślenie jest à rebours wobec przyjętego przez Korczaka sposobu patrzenia na dziecko i jego „teraz”. Wychowanie to nie separacja dzieci i dorosłych, zamykające je w życzliwym ,getcie” (Ariès 1995), to raczej wzajemne wzrastanie wobec codziennych problemów, z którymi i dzieciom, i dorosłym przychodzi się mierzyć, czy tego chcą czy nie. Sytuacje problematyczne, czyli okazje wychowawcze, nie powinny być także traktowane jako wymówki do tego, aby rozdzielać światy dorosłych i światy dzieci, przypisując tym drugim światom intencjonalną kapryśność (Korczak 1958c: 413) lub niepoważne „życie na żart” (Korczak 1958c: 410), do czego dorośli mają ,naturalną" skłonność, lecz jako sposobności do wyrażania szacunku i wrażliwości, której jako dorośli także od innych ludzi, również tych „mniejszych”, w analogicznych sytuacjach potrzebujemy. Pedagogika Korczaka jest nastawiona - jak się zdaje - przede wszystkim na przełamanie takiego schematu myślowego, ukrywającego głęboką niesprawiedliwość, w którym dziecko z racji niebycia dorosłym jest istotą niższej rangi i mniejszej ważności. Emancypacja, która może tu nastąpić dzięki wychowaniu, musi się wiązać z jednej strony $\mathrm{z}$ podniesieniem rangi dziecka jako równorzędnego podmiotu prawa, $\mathrm{z}$ drugiej zaś z przyznaniem przez dorosłych, że dziecko jest z innego świata, że: „dziecko jest cudzoziemcem, nie rozumie języka, nie zna kierunku ulic, nie zna praw i zwyczajów” (Korczak 1958c: 412). Ta emancypacja jest de facto autoemancypacją, ponieważ może zostać dokonana tylko dzięki działaniom dorosłych, powinni oni odrzucić degradującą człowieka wersję kultury, w której wysiłek poznawczy i fizyczny nastawiony jest na opanowanie i zneutralizowanie Innego jako potencjalnego źródła kłopotów. Najlepiej napisane prawa nie będą wiele warte, gdy dorośli swoją postawą i myśleniem będą psuli dzieci, a będą one zarówno „zepsute przez wzgardliwe pomiatanie prostactwa i niedostatku”, jak i „zepsute przez zmysłowe, pieszczotliwe lekceważenie przesytu i wyrafinowania" (Korczak 1958c: 418). Oznacza to zarówno sytuację, w której dzieci są „niewidzialnym” dodatkiem do życia dorosłych, jak i sytuację ich „upupienia” (by użyć wyrażenia Gombrowicza), niepozwalającego wyjść im ze schematu rodzicielskiego uzależnienia.

Tak rozumiana emancypacja zaznacza się w przyjęciu innej wersji odpowiedzialności, różnej od odpowiedzialności za kogoś. Chodzi mianowicie o odpowiedzialność wobec bycia tym, czym dziecko jest; o odpowiedzialność związaną z uznaniem, że wychowanie jako wspólne życie wymaga wspólnych działań nastawionych na realizację „teraz” dziecka, nawet jeśli to „teraz” wynika z jakiegoś ,przedtem” i będzie miało swoje „potem”. Korczak podkreśla w formie apelu: „Rośnie nowe pokolenie, nowa wznosi się fala. Idą z wadami i zaletami; dajcie warunki, by wzrastali lepsi” (Korczak 1958c: 422) oraz „Nie jesteśmy cudotwórcami - nie chcemy być szarlatanami. Zrzekamy się obłudnej tęsknoty do dzieci doskonałych" (Korczak 1958c: 423). To wezwanie przede wszystkim upominające się o odpowiedzialność za dziecko, które jest dopiero w trakcie rozwoju (i w tym sensie myśl Korczaka przekracza program progresywistów), lecz także wobec dziecka, któremu przyznaje się - podobnie jak wychowawcy - możliwość błędu, pomyłki, niedoskonałości w dniu dzisiejszym oraz autonomię na miarę potrzeb i możliwości realizowanych w dialogu, a zatem poprzez obecność dziecka. Bez tej nauki wspólnej odpowie- 
dzialności dziecko nie będzie miało szans na usensownienie własnego życia, ponieważ już jako osoba dorosła będzie nadal lokowało znaczenie swojego istnienia w nieokreślonej przyszłości, fantazmatach lub nawet zaświatach. A ponadto bez tej odpowiedzialności realizowanej z dzieckiem nie zdobędzie ono przyzwolenia na prawo do odpowiedzialności za siebie i za swoje wybory.

Odpowiedzialność wobec drugiego człowieka jest zatem odpowiedzialnością odsłaniającą świat wyborów i wolności, a nie odpowiedzialnością zasłaniającą możliwość tworzenia człowieka również przez samego siebie. Człowiek jest oczywiście istotą społeczną, czyli tworzoną przez okoliczności społeczne, lecz podkreślanie tej zbiorowej przewagi nad indywidualną wiedzą i kompetencjami musi prowadzić do sytuacji negatywnie rozumianego konformizmu i zgody na społeczną przemoc, a w konsekwencji - do zaniku rzeczywistej odpowiedzialności, czyli autoodpowiedzialności. Korczakowskie rozumienie uczestnictwa w kulturze - również w kulturze dziecięcej - wiąże się z uznaniem dzieci za istoty, wobec których należy dobrowolnie, tj. zgodnie z dobrą wolą $\mathrm{w}$ sensie kantowskim, zrezygnować z poczucia wyższości swoich interesów i wartości i zwrócić się ku aktualności każdorazowej pozycji dziecka, dążąc tym samym do zaakceptowania go takim, jakim jest. Brak realizacji tego postulatu będzie prowadził do tego, że słowa Korczaka: „Baczność: życie współczesne kształtuje silny brutal, homo rapax; on dyktuje metody działania. Kłamstwem są jego ustępstwa dla słabszych, fałszem cześć dla starca, równouprawnienie kobiety i życzliwość dla dziecka" (Korczak 1959c: 423), nadal będą naszą teraźniejszością.

\section{Literatura}

Archer M.S. (2019), Kultura i sprawczość. Warszawa, Narodowe Centrum Kultury.

Ariès Ph. (1995), Historia dzieciństwa: dziecko i rodzina w dawnych czasach. Gdańsk, Marabut.

Bruner J. (2006), Kultura edukacji. Kraków, Universitas.

Buliński T. (2002), Człowiek do zrobienia: jak kultura tworzy człowieka. Studium antropologiczne. Poznań, Wydawnictwo Poznańskie.

Hartkamp P. (2017), Zamiast edukacji przymusowej. Apel o przestrzeganie praw dziecka w edukacji. Gliwice, Element.

James W. (1998), Pragmatyzm: nowe imię paru starych sposobów myślenia. Warszawa, Wydawnictwo KR.

Kant I. (1995), Co to jest Oświecenie? W: I. Kant, Przypuszczalny początek ludzkiej historii i inne pisma historiozoficzne. Torun, Comer.

Kłoskowska A. (1980), Kultura masowa. Krytyka i obrona. Warszawa, PWN.

Kohlberg L., Mayer R. (2000), Rozwój jako cel wychowania. W: Z. Kwieciński (red.), Alternatywy myślenia o/dla edukacji: wybór tekstów. Warszawa, IBE.

Korczak J. (1958a), Momenty wychowawcze. W: J. Korczak, Wybór pism. T. III. Warszawa, Nasza Księgarnia.

Korczak J. (1958b), Jak kochać dziecko. W: J. Korczak, Wybór pism. T. III. Warszawa, Nasza Księgarnia. 
Korczak J. (1958c), Prawo dziecka do szacunku. W: J. Korczak, Wybór pism. T. III. Warszawa, Nasza Księgarnia.

Lovejoy A.O. (1999), Wielki łańcuch bytu: studium z dziejów idei. Warszawa, Wydawnictwo KR.

Nawroczyński B. (1947), Życie duchowe. Zarys filozofii kultury. Kraków-Warszawa, Wydawnictwo A. Piątkowski.

Olczak-Ronikier J. (2011), Korczak. Próba biografii. Warszawa, W.A.B.

Postman N. (2001), W strone XVIII stulecia. Jak przeszłość może doskonalić nasza przyszłość. Warszawa, PIW.

Smolińska-Theiss B. (2013), Korczakowskie narracje pedagogiczne. Kraków, Oficyna Wydawnicza „Impuls”.

Strain J.P. (1975), Idealism: A Clarification of an Educational Philosophy, „Educational Theory”, 25.

Szczepska-Pustkowska M. (2011), Od filozofii dzieciństwa do dziecięcej filozofii życia: casus władzy (i demokracji). Kraków, Oficyna Wydawnicza „Impuls”.

Śliwerski B. (2007), Pedagogika dziecka. Studium pajdocentryzmu. Gdańsk, Gdańskie Wydawnictwo Psychologiczne.

Tillmann K.-J. (2013), Teorie socjalizacji. Społeczność, instytucja, upodmiotowienie. Warszawa, PWN.

Tyszka A. (1971), Uczestnictwo w kulturze. O różnorodności stylów życia. Warszawa, PWN.

Weber M. (2002), Gospodarka i społeczeństwo: zarys socjologii rozumiejącej. Warszawa, PWN.

Wojnar I. (2000), Humanistyczne intencje edukacji. Warszawa, Wydawnictwo Akademickie Żak. 